\title{
The Portrayal of Nineteenth Century's Byronic Hero in Don Juan
}

\section{Muhammad Ishtiaq}

Lecturer, Department of English Port City International University, Chattogram, Bangladesh Email: ishtiaq.reza91@gmail.com

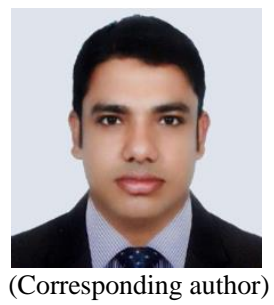

\author{
Article History \\ Received: 7 January 2022 \\ Revised: 16 February 2022 \\ Accepted: 19 February 2022 \\ Published: 21 February 2022
}

\begin{abstract}
The goal of this article is to look at the nineteenth-century Byronic Heroes, based on Don Juan by Lord Byron. It demonstrates how he embodies this poem as an 1819 poem with social value due to its original concept. It investigates Byron's attitudes to culture through portraying the major characters along with primary depictions of upper-class parents, which is one of the visions of England in the nineteenth century. It also focuses on Byron's representation of nineteenthcentury attitudes on romantic writing and the exact scenario of extramarital affairs. This study delineates gender discrimination and its influence on social lives in the nineteenth century. The main focus of this research is how Don Juan demonstrates Byronism through portraying authentic characters, attitude to living conditions, the impact of parents and religion, revolution, and class judgment.
\end{abstract}

Keywords: Byronism; Social value; Extramarital affairs; Gender discrimination; Class judgment.

\section{Introduction}

In 19th-century English literature, Lord Byron's satirical epic poem (Don Juan 1819-1824) exposes Don Juan as a man who is easily prejudiced by women, rather than as a dissipated person. A "Byronic Hero" is a character from 19th-century English literature who appears in the epic poem Don Juan, which is allocated into sixteen cantos and written in the 'Ottava Rima' language. Byronism formed a lot of the cultural and intellectual moments of the second half of the nineteenth century. According to Byron, "the poet's private and public life, as well as the darkly heroic characters he created, which were demonstrated in his philosophical conception of himself and his place in the world" (Hocutt, 1996). One component of the Byronic hero phenomenon was Byronism. The second half of the poem is almost entirely dedicated to the conspiracy. Byron's acrimonious tirades on England's authority, class, wealth, honor, poets, and diplomats for much more are interesting. Don Juan holds a lofty place among literary ridicule, and it was incomplete at Byron's end of life.

Lord Byron, an English Romantic poet, based the persona on the Spanish legend of Don Juan, but not the story. $\mathrm{He}$ is a fabricated libertine who is also known as "Don Giovanni." El Burlador de Sevilla y convidado de piedra, a $17^{\text {th }}$ century drama by Tirso de Molina, is a classic retelling of the story. Lord Byron's concept of a protagonist differs from that of other Romantic poets in that he believes a protagonist should be a real person with dynamic human emotions and proficiencies, thus he bestows separate chapters to thematic and stylistic considerations. Don Juan is a depressed psychiatric phrase derived from Don Juan which has become a generic representation of a womanizer.

Byron's poetry was widely interpreted as having been written by someone who valued erogenous feelings, immortal anger, and haughty intransigence, and lacked moral judgment. Don Juan's story does not follow epic tradition, though Lord Byron said that Don Juan was to be an epic poem. His writing is a medium for a digression on any and every subject and person that entered Byron's mind. As we know, some qualities are ordinary, and these qualities constitute the concept of a Byronic hero as far as his role and function are concerned in the poem. The Byronic heroes are all over the poem. Lord Byron's portrait of the Byronic Hero is as cynical, whimsical, and highly romantic as they come. Besides this characteristic attitude, they are libertines, sadistic, jolly, and naughty. Generally, they are handsome but cruel and careless about any serious issues. 
Don Juan is deliberate as a typical Byronic hero and plays a profoundly serious role in this famous poem. Byronic heroes also tend to be characterized as intelligent, ruthless, arrogant, violent, self-concern, selfstrike, manipulative, self-caring, self-slaughterhouse, spiritually doubtful, suicidal, grumpy, seductive, sexually appealing, and emotionally oppressed.

Through Byron's semi-autobiographical epic narrative poem Childe Harold's Pilgrimage (1812-1818), the Byronic hero first reached a very wide audience all over the general population, and then the "Byronic Hero" had an important influence on later literature in English and other languages. It creates an appearance and a way of feeling that is embraced more eagerly in Germany, France, and Russia.

Romantic heroes represent an important tradition in British literature. The Byronic Hero character was originally developed because of Lord Byron. It was named after him in the late 18th and early 19th centuries. It is a feature of a different literary character that existed, which is one of the most prominent literary character types of the Romantic period.

In England, several Gothic novels and dramas, Milton's Paradise Lost, Sir Walter Scott's The Heroic Romances, some of the poetry of Percy Bysshe Shelley, and the works of Lord Byron, all comprise a protagonist who is a Byronic hero. A Byronic hero can be conceptualized as an extreme variation of the Romantic hero archetype. Traditional Romantic heroes tend to be conceptualized by their rejection or interrogation of standard social conventions and norms of behavior, their severalty from the larger society, their ability to inspire others to commit acts of good and kindness, and their focus on the self as the center of existence, On the other hand, Byronic heroes also tend to only seem loyal to themselves and their core beliefs and honor.

Lord Byron speaks about an entirely new genre or subject matter in Don Juan which is a wonderful work of writing. The term "Byronic hero" has usually been reserved for masculine protagonists. A Byronic hero is a character that thinks and battles with his difficulties, and whose views and internal conflicts are strongly idealized, with some being depicted with the suggestion of horrible crimes or tragedies in their past. A Byronic hero is a fictional character who rose to prominence in the nineteenth century as all poets began writing poems about various heroes such as Classical Heroes, Ordinary Heroes, Superheroes, Tragic Heroes, Epic Heroes, and Anti-Heroes. The poet is writing about Byronic Hero in this poem. Not even the heroes, who frequently blossomed to this level, though they did exist before him, were propagators of this type of personality in Byron's writings. The term defines the type of the main character found in many fictional works by Lord Byron, who is said to have had this type of personality. As Byron echoes in the first canto of Don Juan, "I want a hero; an uncommon want." (Byron, 1912).

A hero is a central figure in a story, hence Byronic heroes are the protagonists or central figures in any story they appear in. In literary criticism, the term "Byronic hero" refers to a type of character that can be found not only in other works of literature but also in Byron's own. A Byronic hero is a literary character who is depressed and haunted by a tragic past secret. Many people only remember the poem from the first episode: it's filthy, hilarious, and obscene, and it's bad for Don Juan's reputation that Canto One is the first canto where everyone knows who he is, and it's another of those Byronic hero facts. There are various character and theme pairs in this poetry. Among the most prominent topics are family, sex, youth, gender, and sexuality.

Family, sex, youth, gender, and personalities like "Don Juan, Don José, Donna Inez, Donna Julia, Don Alfonso, and Antonia" are among the most prominent topics. This poem's main characters are listed below. Juan is preoccupied with sexuality, escape ingenuity, sting, and disobedience as a Byronic hero. He may look to be a rascal or a villain, but unlike villains, he can recruit our attention. It is contingent on this. Don Juan which means The Byronic Hero, is my personal favorite. After reviewing these, I discovered that the Byronic Hero is significant because it was developed in the nineteenth century yet continues to be relevant in literature today.

\section{Literature Review}

Lord Byron's portrayal of Don Juan as a Byronic hero, which has been scrutinized by several specialists and scholars, is authentic, and this poem provides a valuable historical source, not only for historical information but also for the actual details and characters that characterize nineteenth-century romantic literature. The attention to correct details, as well as the work's admirable and horrible aspects, makes it stand out. Following previous writers, Lord Byron devoted prominence to the portrayal of historical events, relationships, and characters in Don Juan by representing eighteenth-century concepts and the influence of French Romanticism, which had repercussions in England as well as the romantic period. He is attempting to represent a true story from his life (autobiography) in his poetry, as well as how life continues in this situation. "The Byronic hero, incapable of love, or capable only of impossible love, suffers endlessly. He is solitary, languid, his condition exhausts him. If he wants to feel alive, it must be in the terrible exaltation of a brief and destructive action." (Camus and Gilbert, 1948).

The Stranger is a fictional novel published by the critic Albert Camus in the nineteenth century. He stated in his valuable writing about the Byronic Hero that this type of hero is too distinct from others because of their loving style, as they are capable of impossible loves yet are trustworthy, and they must suffer greatly for their choice. "I'm not Byron, it's my role to be an undiscovered wonder, like him, a persecuted wanderer, but furnished with a Russian soul. I started sooner, sooner ending, my mind. Will never reach so high; within my soul, beyond the mending, my shattered aspirations lie: Dark Ocean answer me, can any Plumb all your depth with skillful trawl? Who will explain this to me? I... perhaps God? No one at all?" (Lermontov, 1840)

Another critic, Russian romantic writer Mikhail Lermontov, wrote about Byronic Hero in his journal. "A hero for all times" implies that the Byronic Hero as a figure is unknown, that their intellect does not reach such heights, and that they do not receive solutions to any mental questions. 
"Cynical, self-deprecating, affected, indiscriminate, patronizing, immature, as sloppy intellectually as he was with his desk, fickle, vain, virile, brooding, pedantic, philandering... in short, Byronic, Byronic, Byronic, almost to the point of parody." (Woollett, 2014)

It is the 2014 debut novel by Australian writer Laura Elizabeth Woollett. Where he describes the Byronic Hero's characteristics and their attitude. He looked thunderstruck for a moment, and ejaculated: 'A Byronic hero -! Oh, my God! Why you abominable" (Heyer, 1818)

Georgette Heyer's Regency romance novel Venetia was released in 1958 and is set in England in 1818. It's a romantic tale about a woman on the verge of widowhood who falls in love with a rogue. Where the author adds to the legions of Byronic heroes who have populated love literature since Lord Byron first took up the pen The Byronic hero is well-versed in the world of romance authors and readers. A Regency rogue has stolen that special sort of the scary, shadowy, misconstrued heart of many a sheltered young Regency girl. Georgette Heyer suggests that she has influenced the legions of Byronic heroes that have populated romantic writing since Lord Byron first arrived in Venetia. "Goethe in Weimar sleeps, and Greece, long since, saw Byron's struggle cease." (Arnold, 1941)

Delphi Complete Poetical Works by Arnold (1941), Delphi Complete Poetical Works of Matthew Arnold (Illustrated)", is a series that offers readers the works of literature's premium poets with loftier structure. This volume presents the complete poetical works of "Matthew Arnold" and an illustration of the Byronic Hero.

"Awoke one morning and found myself famous." Beautiful, seductive, troubled, brooding, and sexually adventurous, he was living the life of a Byronic hero while creating the archetype in his poetry.

. She famously declared him to be "mad, bad, and dangerous to know," which he was. So, was she?" (Isaacson, 2015)

Another American author, described in his articles about Byronic Heroes, depends on Lord Byron's Don Juan.

"Among the other features of the romantic persona, "the character Byron created is a handsome young person, of impressive aristocratic origin, rejecting and being rejected by his class; -------------; or a rebel and radical by the English standards of his day." (Golban, 2005).

The Pilgrimage of Childe Harold is the first work in which Byron developed his romantic figure, subsequently dubbed the "Byronic hero." In an aristocratic household, "Childe" refers to the first-born male child, implying a personal noble position. It isn't always synonymous with the word "kid." Our first Byronic hero, Harold, is the name of Byron's protagonist in this poem. The word "pilgrimage" has no religious connotation; it simply refers to Harold's journey. Since it was composed during Byron's exciting voyage and portrays Byron's travels, critics claim that this work is based on Byron's personal travel experiences. This poem is thus classified as an "autobiographical poem." Childe Harold, disillusioned with his aimless life of pursuing pleasure, finds solace by embarking on a solitary voyage to distant regions (Britannica, 2021). Many commentators have pointed out that Lord Byron is the first Byronic hero we meet; he represented himself via his characters. "A man proud, moody, and cynical, with defiance on his brow, and misery in his heart, a scorner of his kind, implacable in revenge, yet capable of deep and strong affection." (Macaulay, 1843)

The Byronic hero has been portrayed as suspicious, desolate in heart, and irritable by critic Lord Macaulay and historians, but he must have a profound and firm attachment which of the following best describes the Byronic Hero in Lord Byron's Don Juan.

\section{Methodology}

The research technique refers to a certain method or theory for analyzing a literary piece. My research is a qualitative method that collects and analyzes non-numerical data to derive meaning from it, which helps us enjoy the study. Qualitative research employs content analysis and descriptive qualitative research approaches. The data source for this study is a written document of literary results from Lord Byron's poem Don Juan from the nineteenth century. In essence, this thesis report and inquiry are based on primary and secondary sources and built utilizing the expressive and logical technique. The goal of this research is to locate and characterize the uses of the new phrase Byronic Hero in England throughout the nineteenth century. In my report analogy, the majority of the authors, as well as students and researchers, have been critically evaluated and studied, and some knowledge and material related to them have been collected.

\subsection{Research Questions}

1. What are the societal attitudes on Byronic heroes that have diffused throughout English literature in England?

2. How does Lord Byron portray female characters and portray extramarital affairs?

3. What is Byron's concept of the Byronic Hero?

\section{Discussion and Finding 4.1. Definition of Byronic Hero}

Any character is shown after Lord Byron is referred to as a Byronic hero. A Byronic hero has various features, and he can be called a rebel in many ways. Byron's ideas were developed and enlarged through his poetry. "The term Byronic hero is used in literary discussions to designate a sort of character who appears not only in Byron's writings but also in a wide range of other works of fiction. As a poet, Byron was able to weave his distinct cultural ideas and thoughts into a narrative of a Byronic hero with typical and rebellious characters." 1996 (Ma). Many of Byron's works are infused with the facts of the Byronic hero, and Byron himself is measured to represent many of these literary truths. The Byronic hero, on the other hand, possesses several enigmatic skills; "heroic features" are not retained by him in the traditional sense. 
The Byronic hero, on the other hand, possesses several enigmatic skills; "heroic features" are not retained by him in the traditional sense. The Byronic hero, suffusing much of his work by transitory the points of kinds of figures, presents an idealized, but defective character whose outside aspects include the idea revolt, lack of respect for rank bullishness or absence of forethought great desire and honor, great capacity, a distasteful undisclosed past, superiority, and eventually a self-destructive manner which we can find. Aside from the influence of such external attributes, the Byronic hero frequently exhibits enduring love for life, the pursuit of romance, the audacity to challenge the royal, disrespect for unfair social justice, vengeance against the wicked party that robbed the people of their liberty, and the desire for freedom.

These qualities appear to be the same as the image in Criticize Bravery, and they are highly regarded in a variety of civilizations. However, judging just based on outdoor attributes and cross-cultural identification, it is a bit hasty to conclude that the Byronic hero is based on the Criticize Bravery framework. According to the words and actions of proof presented by Byron, the outer attributes are informal and unstated. The inner, or hidden and delicate internal features, on the other hand, are solid to obtain their indications. Inside the mystical activity, inherent traits emerge. The external appearances are described in detail, but crucial characteristics necessitate regular reading of the words to decipher indirect indications offered by Byron to his readers, as we can see. The outside and internal attributes appear to be at odds, but it's difficult to separate the two. Since the era in which Byron lived, we can indicate the effect of traditional morals about heroes in the Byronic hero, it is still necessary to distinguish them. A Byronic hero is a fictional character who is a threatening dissident, angry, and usually bothered by an unknown past event. He is often isolated from society as a wanderer or as a refugee of some type.

\section{"This strange -- but true; for truth is always strange. \\ Stranger than fiction;" (Byron, 1912)}

By using this statement, the author is attempting to convey the idea that facts are sometimes more difficult to trust than fiction. A Byronic hero is a mix of good and evil; he isn't moral or noble. Whether this social deviation is forced upon him by an outside force or is self-inflicted, the Byronic hero is a guy with great personal characteristics, unseen wickedness, and many other adaptable attributes that are primarily obvious. Lord Byron (1788-1824) coined the phrase "Byronic Hero" to describe the type of central character found in many fictional works who is said to have possessed this kind of disposition. Don Juan is good-looking, eye-catching, and fascinating as a Byronic hero and protagonist. Because of his beautiful qualities and fearless daring for women, he becomes a heart pulse. These lines in Don Juan reveal Juan's physical attraction: "Young Juan was sixteen years of aye tall handsome, slender but well-knit" - (Byron, 1912)

Byron has long been regarded as one of the greatest Romantic poets of the 19th century. The Romantic Movement, which arose from the Enlightenment, reached its pinnacle thanks to Byron's writings. Byron is not only based on the poetry he has written, but also on similar reviews and assessments. Byron's hero has been vividly depicted in his poems during his brief life. In his poems, Byronic heroes are frequently addressed, especially in longer pieces. Scholars have traced the literary legacy of the Byronic hero back to John Milton, as well as many Romantic Movement authors and artists, including Charlotte and Emily Bronte, who drew inspiration from Byron during the nineteenth century and beyond. These poems are known as "Epic of Rebels" because of their portrayal of the Byronic hero (Jiang, 2010).

Byronic hero's personality reflects other internal attributes with the careful analysis of his poem:

"Yet so my heart forebodes but must not fear.

Nor shall my followers find me falter here.

We'll furnish mourners for our funeral pile." - (Byron, 1814)

The individuality that appears almost unsociable even when isolated from the rest of the world, a proclivity to go to extremes in terms of tolerance, a refusal to accept advice from others, and an aimless battle with his verdict. These characteristics do not exist in the Criticize Heroism's traditional structure.

\subsection{Byron's Treatment of Women in 19th-Century Society}

In the nineteenth century, women and men were not the same. Women were referred to as the "pathetic sex." Because they had no reason to leave the house or go to work, the largely afflicted middle class did not have to be concerned with things like deficient women. Because of their shortcoming, the middle classes took women's roles very seriously. Women are treated with contempt and disapproval by Byron throughout Don Juan. Byron uses his humor and satiric comedy to expose his prejudice and selfishness, to expose women for what he feels they are.

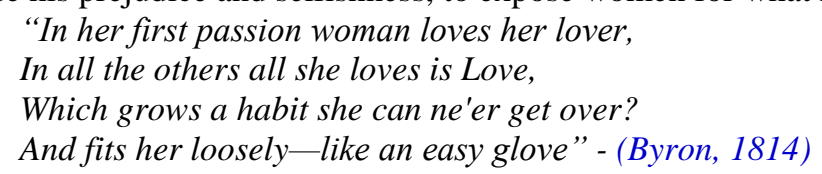

Byron generalizes about nineteenth-century women by stating that all women adore the first man with whom they have intercourse, but after that, they only love the idea of love. It's the difference between loving a man for who he is and loving someone because you want your life with him to be like a romantic comedy. The first is based on the individual, whereas the second is based on the concept of a connection. Don Juan is not simply a man's harsh criticism of a group of people who fail to live up to his expectations of them, but also a man's poem about women. The specifics of Byron's life, such as his bad relationships with women, which culminated in his disastrous marriage and harsh parting, and his idea that he was the most followed of all poets, cannot be completely avoided.

"A little still she strove, and much repented,

And whispering, 'I will ne'er consent'-consented." - (Byron, 1814). 
This phrase depicts a 19th-century woman named "Donna Julia" attempting to pursue a connection with a younger Juan, and it reflects how women at the time attempted to sustain extramarital partnerships. This was pretty common at the time. On the other hand, in the second canto, we encounter "Haidee," a positive character who is sufficiently honest, and Juan finds peace with her.

\section{"Haidée and Juan were not married, but}

The fault was theirs, not mine: it is not fair,

Chaste reader, then, in any way to put.

The blame on me, unless you wish they were" - (Byron, 1814).

Byron has been writing on a sexual relationship between Juan and Haidée, which he concedes would have been impure in his time. However, he encourages the audience not to hold him responsible because it was Don Juan and Haidée who chose to have sex. We met the sultan's fourth wife, Gulbeyaz, in canto X.

"Fate is a good excuse for our own will),

And caught them... “- (Byron, 1814).

'Lady Adeline' is the subject of this line. Byron makes fun of them for having a relationship. Byron sets the scene for the affair hinted at in Canto XIII while mocking the English upper classes at the same time. Don Juan, as we all know, is a Byronic hero who had numerous girlfriends in his life. As a result, if we look at the whole picture, Lord Byron portrays an unfavorable image of most women at the time. At the very least, he aimed to show how women were treated in the nineteenth century, how their attitudes shifted from class to class, and how authority might be abused to further one's own goals. By maintaining equality and inequality between educated and illiterate women, he provides a good portrayal of 19th-century ladies in this poem.

\subsection{Significance of the Genre 'Romance' in Don Juan}

Lord Byron, a well-known romantic poet in English literature, coined the term "Byronic Hero." Romance is a characteristic of a love tale or romantic connection that is "positive, cheery, and expressively sufficient." The Byronic Hero is simply a representation of the genre romance in Don Juan, which is adopted by numerous writers. In 19th-century Western literature, Byronic characters such as Manfred, Don Juan, and The Corsair are particularly well-known. Nearly every protagonist or hero appears in Byron's epic poems. Some instances of Byronic Heroes are Heathcliff from Emily Bronte's novel Wuthering Heights, Mr. Darcy from Jane Austen's novel Pride and Prejudice, Claude Frollo from Victor Hugo's The Hunchback of Notre Dame, and Captain Ahab from Herman Melville's Moby Dick. As a result, this genre gained widespread popularity in the nineteenth century and continues to exist now.

\subsection{Byron's Attitude on Society}

In Don Juan's 17 cantos, we witness him obtaining new experiences at every turn while also producing difficulties in society. In canto 1 , he recognizes his family troubles and learns about the illicit relationship, which fundamentally alters his perspective. Simultaneously, he is involved in an unlawful relationship that no one in society approves of, and he is sent somewhere to correct his character flaws. Then, from Canto 2 to 18 , we witness Juan being compelled to make various options based on the society at the time. Juan just serves as an introduction to life in England. The fundamental objective of Byron's setting Don Juan in the aristocratic environment of early nineteenth-century England is to expose the world's shallowness, hypocrisy, and self-interest. "Society has become one polished horde, composed of two strong tribes, the Bores and the Bored." - (Byron, 1814)

"Society is now one polished horde, Form'd of two mighty tribes, the Bores and Bored." - (Byron, 1814)

Don Juan provides relief from this anxiety by categorizing social interactions into two groups: those who bore others with their monotony while demanding to be important and socially or intellectually "polished," and others who are bored by the first group's affectations. Byron, on the other hand, could take a step back and consider the civilization around him. Someone as clever and active as Byron, looking at society with a more objective pair of eyes, would necessarily find the numerous rituals incorporated into social occasions quite uninteresting. Byron must have felt pressured to act effectively while bored by such encounters and others' posing. Lord Byron's reflection is seen in Don Juan because it is his autobiographical work, and it can be claimed that Byron never wanted to follow the natural principles of society; instead, he wanted to create.

\subsection{Compare and Contrast Between Byronic Heroes and Other Heroes}

In literature, a hero is typically the central or major attraction. In the course of the story or happening, the hero figure may possess great or admirable abilities and be required to overcome challenges. The romantic writer Lord Byron, who created whole new heroin in nineteenth-century literature, is credited with the invention of the Byronic hero. The major distinction between Byronic and other heroes is seen in their attitudes and works, which they define. A Byronic hero, as we know, is perceptive, very intellectual, cultured, classy, cunning, but also self-interested, flexible, and their most significant attitude is that they are vicious most of the time rather than expressly delicate, which may translate into being emotionally conflicted, or irritable. The rest of the heroes, on the other hand, are not like that. Like a Byronic hero, all heroes, whether romantic, classical, epic, tragic, or anti-hero, share some characteristics.

\subsection{Reflection of Romanticism in Don Juan}

The Romantic era, or period, is also known as "Romanticism." It is a literary, innovative, and well-informed movement that began at the end of the 18th century in Europe. Between 1800 and 1850, it was at its peak. With time, the meaning of romanticism has evolved. It is characterized by its emphasis on sensation and uniqueness, as 
well as reverence for the past and nature, with the 17 th century preferring the medieval over the classical. Due to the creation of a new literary genre, "romantic" signifies creativity or fantasy. In contrast to spiritual documents transcribed in Latin, stories, or fiction manuscripts, were printed in dialect meaning romantic languages. The "Age of Enlightenment" in the eighteenth-century eclipses Romanticism, in which everything is seen through the lens of science and reason. In England, the term "romanticism" was then accepted. The first generation of poets includes 'William Wordsworth, William Blake, and Samuel Taylor Coleridge.' The second generation includes 'William Wordsworth, William Blake, and Samuel Taylor Coleridge.' The second generation, on the other hand, is made up of 'Percy Shelley, George Byron, and John Keats.' With François-René de Chateaubriand-Atala (1801), René (1802), Le Génie du Christianisme (1802), and Germaine de Stael: De l'Allemagne (1802), Romanticism expanded France at the start of the nineteenth century (1813). Lord Byron's poem Don Juan began in 1818 and Byron's death in 1824 left the poem's 17 cantos unfinished. In contrast to the legendary Don Juan, who is known for his unusual heroism? Don Juan of legend and earlier literary deeds, when contrasted with Byron's unusual behavior of the leading character, might be debated in terms of these unique characteristics concerning individualism and non-orthodoxy. Byron was a Romantic, according to his other works and the period in which he lived.

"Thou shalt believe in Milton, Dryden, Pope;

Thou shalt not set up Wordsworth, Coleridge, Southey;

Because the first is crazed beyond all hope,

The second drunk, the third so quaint and mouthy:" - (Byron, 1814)

Don Juan should be seen as a statement of Byron's perspective on Romanticism's formalism, with a focus on the poet's persona, common topics, and the importance of emotion or sentiments. Don Juan, the protagonist of the tale, is a religious renegade who broke society's morals and was punished as a result. Don Juan is an ambiguous figure, viewed as an anti-hero by those writers and creators who depicted him as a proclamation about man's selfdeclaration in an unfair and insincere society. Don Juan, Byron's best poem, is an astounding fundamental irony that depicts the male caprices behind Romanticism and nineteenth-century public culture through the legend of Don Juan. As a result, Don Juan's preservation of romanticism is acceptable.

\subsection{Features of Byronic Hero}

Literary Devices are used in any type of work by any writer. The meaning of the story is conveyed through the employment of an individual style of writing by the feature. This requirement is aided by the employment of literary elements or features. Similes and metaphors, onomatopoeia, imagery or figurative language, climax, and other methods are examples of these devices. Byron displays authorial interruption several times in Don Juan. He portrays, for example, that he prefers tall ladies with gorgeous eyes. On the other hand, he analyzes his writing with similes and rhyming, as well as absolute speeches, in which he is deliberating definite characters. By suspending himself, he directly criticizes William Wordsworth. The poem's comic effect is enhanced by the authorial interruptions. As a satirist, Byron's portrayal of one of history's most famous seducers in a concerning light was most likely done on purpose to establish credibility.

\section{Conclusion}

The prominent trait "Byronic Hero" is evaluated in this study. This characteristic comes from George Gordon Byron's poem Don Juan. Lord Byron presents the unusual principal character Don Juan in this poem, which is based on his own life. This undergraduate thesis aims to depict the situation of England and society's thinking during the romantic era. Today, the word 'romantic' conjures up ideas of love and tenderness, yet the phrase has a much broader meaning. It safeguards a variety of developments in art, philosophy, literature, and music from the late eighteenth and early nineteenth century. He also explains how women had a part in the nineteenth century and how society differentiates men and women based on their own opinion through this feature. This feature primarily promotes a key concept on 'Byronic Hero.'

Throughout my analysis, I have found a Class distinction, Romantic Movement in the century of 19th, women's involvement easily with anyone, situation during the French revolution, Extra marriage affairs, and situation of the society. Don Juan is by no means entirely responsible for this entire unlucky and bad situation, but his ruthless fate and the surrounding society were largely responsible for his becoming a Byronic hero or cultivating Byronism into him. This feature Byronic Hero has been a milestone since the 19th century to the modern age and this feature also differentiates Love into two types "Byronic and platonic". At least to conclude the topic, 19th centuries Byronic hero by Gorge Gordon Lord Byron demonstrate exclusively in Don Juan, and the strong fact in 19th century English literature.

\section{References}

Arnold, M. (1941). The oxford dictionary of quotations. The Oxford University Press.

Britannica, T. (2021). Editors of Encyclopaedia, Childe Harold's Pilgrimage. Encyclopedia Britannica. Available: https://www.britannica.com/topic/Childe-Harolds-Pilgrimage

Byron, L. (1814). Don Juan. 1st edn: Kessinger Publishing: United Kingdom.

Byron, L. (1912). Don Juan. Published Posthumously: United Kingdom.

Camus, A. and Gilbert, S. (1948). The plague. Hamish Hamilton: London.

Golban, P. (2005). Hypostases of the byronic hero. Available: www.Academia.edu

Heyer, G. (1818). Venetia. William Heinemann. Print (Hardback and Paperback): United Kingdom. 
Hocutt, D. (1996). Byron's influence on the creation and development of the nihilist bazarov in ivan turgenev's fathers and son" ivan turgenev's bazarov roots in byronism. Available:

https://facultystaff.richmond.edu/ dhocutt/pdf files/bazarov.pdf

Isaacson, W. (2015). The Innovators: Simon and Schuster published a revised electronic edition. Print (hardback and paperback): United States.

Jiang, F. (2010). Byronic characters an intimate study in a modern context. International Journal of Creative Research Thoughts (IJCRT), 7(2): 96-102.

Lermontov, M. (1840). A hero for our time. Iliya Glazunov and Co: Russia.

Macaulay, B. (1843). Critical and historical essays. 2 vols. Beatty, Beatty.

Woollett, L. (2014). The wood of suicides. The Permanent Press: United States. 